\title{
The influence of Leadership, Working Environment and Employee Performance Against Budgeting Process
}

\author{
(Case Study Cipta Karawang In Manufacturing Company in the Industrial Park)
}

\author{
Nursito, Dewi Faeni
}

\begin{abstract}
Research aims to understand the influence of leadership, work environment and employee performance against budgeting. The study is done the research was done to 211 respondents of the population 350 by spreading the questionnaire to supervisor, managers and part accounting and financial to companies manufacturing in the industrial park solar copyright karawang. Test the questionnaire was also made of 55 respondents before the research was done. Model analysis using structural equation a model (SEM)
\end{abstract}

The results of the study revealed that good simultaneously and in full leadership, work environment of employee performance and have had a positive impact and significantly to the budgeting process. Manufacturing in the new company in the industrial park Surya Cipta Karawang.

Over empirical findings this research, the budgeting process manufacturing in the new company in the industrial park solar system cipta west karawang-jawa out step by work environment and to promote a work environment these good more, the commitment of leadership that better the determining factor in whether the first important and workplace second as well as an important factor of employee performance the determining factor in whether to three.

\section{Introduction}

The Globalzation competition the much faster and tight, so that attention from all business to be able to maintain a venture business in the middle of this rapidly as competition [1-2]. If businessmen only concerning the aspect of advantage just financially, the driving force of the run the organization, namely human resources that serve as main capital in making organization keep walking, would gradually crushed by the swift science when the battery is in of an organization not protect and empower human resources are [3-5].

Work environment as the factor that important in influences the performance an employee, because a work environment comfortable it can encourage and trigger directly of employee performance [6]. Work environment is one of the factors that support the success of an enterprise [7-9]. These kinds of environments own consist of physic or

Revised Manuscript Received on July 05, 2019

Nursito, Universitas Budi Luhur,

nursito@budiluhur.ac.id non-physic construction that is attached by employees so that cannot be separated from the development of business of employee performance [10]. Covering the condition of the physical environment office space, equipment, a temperature that fresh, comfortable, and meet standard of requirement worthy of contributions will be given to convenience employees at tasks [11-12]. Work environment non-physical which includes friendliness the stance of the victims employees, us between behavior among colleagues, cherish in attitudes different time opinion, and others is requisite to obliged to continue to build the quality of provoking employees finally gets funded to build the performance of they were constantly [13-15].

For every company management in building of employee performance to other sources of adequate human resources be critical attention [16]. To own companies will not cease to refine and maintain the employees who bertalenta and perform as well in facing rivalry of a business that is increasingly complex [17-19]. A company in a maintain and winning business requires the of an organization to thought about a strategy for the development and for human resource standard berkompetensi good which have resulted in a high of employee performance so the purpose of company can be achieved [20].

With the performance of karyaan good so budgeting will also composed and been implemented well [21].

\section{The formulation problems}

1. Whether leadership influences budgeting process

2. Are working environment influences budgeting process

3. Whether employee performance influences budgeting process

4. Whether leadership, working environment and employee performance influences budgeting process simultaneously

\section{The study of literature}

\subsection{Leadership}

In practice organization said lead containing connotation move, directing, guiding, protect, fostering, example, will support, providing assistance and forth. Wahjosumidjo (1996:349) in suseno (2006:7) kadarman et.all (992: 110) in

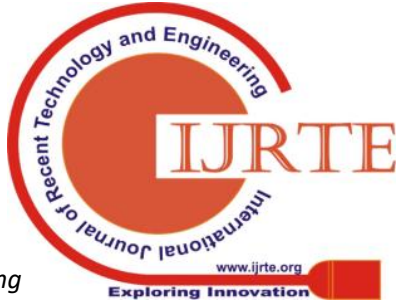


an eddy m (2000: 30$)$ define leadership as the art or process of influence and point people that they want to try to an end to achieve group. Terry (1971: 458) in suseno (2006:7) define leadership as: relationship in which one person, or the leader, influences others to work together willingly on related tasks to attain that which the leader desires

\subsection{Work Environment;}

A condition work environment is said both or appropriate when people would maintain the activity in a optimal, healthy, safe, and comfortable. Conformity work environment can be seen as a result for long periods. Furthermore settings work well as poor may be demanded manpower and more time and not supporting procures design efficient working system.

According to alex s. Nitisemito (2000:183) define working environment is everything around workers who can affect himself in running tugas-tugas who be administered. Working environment in each company has an important role as the workplace affect employees in implementing the tasks, conditions, and his work. Good working environment will cause employees work well and excited.

Terry in hasibuan $(2001: 65)$ that environment work of someone most successful is started from in itself. While sedarmayati (2001:97) define the workplace the whole a tool a utensil and materials faced, environment in which a work, working methods, and setting it works well as individuals and as a group.

\subsection{Employee performance}

Assessment of employee performance is critical for seluruhcperusahaan. To know the increase in about yourself employees dalamcpelaksanaan business it is through an assessment performance. However, performance satisfactory does not happen automatically. The implementation of the performance evaluation of must be able to motivate employees so as to create complacency and composure work and able to create a culture work high

Assess performance must be implemented is constantly being and systematic to obtain the assessment results of the performance objective. Hasibuan (2001:56) said performance on the base is that which is done or not done employees. Organisational performance or the company performance is an indicator levels achievement that can be achieved and reflect the success of manager / entrepreneurs. Sutanto (2002:73) see of employee performance is control the operations of a firm, so if of employee performance have the company performance will increase. But if of employee performance under the standard so the company performance also will decrease. Hence to keep the company performance remain stable so companies need employee who having performance high that enabled firms maintain their existence.

Mangkunegara in the journal febriana wurjaningrum and lories herachwati (2002:7) suggested employee performance is the result of a work as a quality and quantity of achieved by an employee in work in accordance with the responsibility of given him. Hence output good quality and quantity achieved human resources union period of time on its work in accordance with the responsibility of given him.

The declining (2009:124) budgeting process is the financial resources for various purposes man. Bpkp $(2010 ; 28)$ define, budgeting process is financial plan who systematically show allocation of human resources, material and other resources

\subsection{The establishment of the budget participation}

The establishment of the budget is a participation the budget process which is a from top to bottom or from bottom to top , anthony and govindarajan (2005: 373) .According to mahsum et. al., (2009: 49) participation the establishment of the budget phases is part of what is important because of a limited budget that are both ineffective and did not feel at a performance can thwart the programs have already been drawn up before.

\subsection{Budget Discussion}

The budget discussion is a the series of activities to mempertanggung jawabkan all a notion or idea of activities and program would be provided and executed as to progress organization david (2009: 157). Hansen and mowen (2009: 376) the principle the budget discussion basically how budget formed and defended, so goal budget is an effort to discuss the budget is with the business to push through budget as maximum as possible which proposed in the budget discussion.

\subsection{Use of budget}

The use of the budget is the authority for this purpose or program that we have is set forth in a budget work plan activities.This (2011: 29). While the use of the budget according to david $(2009 ; 180)$ is an authority specifically given by a superior to perform activities has been proposed before it was responsible for progress organization.

\subsection{The revision of the budget}

The revision of the budget is the provision of authorization to the revision of the budget when original budget had already been agreed based at the base significant changes in the condition. According to anthony and govindarajan (2005: 391). The revision of the budget can be occur because of new development, because of a change of manager budget is the authority or leadership of to mempermuda or complicate in the amendment of articles .Siegel (2006: 6) the realization of income is the level of achievement of budget, expenditure, transfer, a surplus of / a deficit and the finances of an entity reporting each of which compared with the budget .According to mahsum (2009: 155) is the means to execute the strategy to be prepared for organization and the best there is any digression so that they do not,

\section{Research teoritik model}




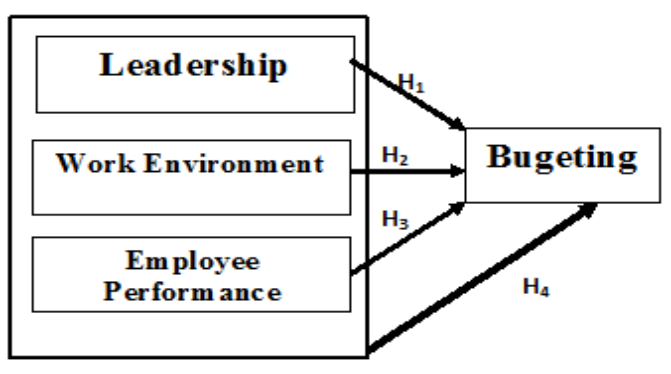

Figure 1 model teoritik research

The same on the many, can be determined her hypothesis: there are significant impact leadership, work environment and kierja employees against the budgeting process good in full simultaneous maupin .Research methods that were used in this research was a method of surveying with the approach causal to analyze the influence of variable use structural equation between a model (SEM) run through amos 20 as the tools the analysis. Respondents used in one series 211 people. This study was conducted in manufacturing concerns in the industrial park surya cipta west karawang-west java

\section{The discussion}

Testing structural equation a model (SEM)

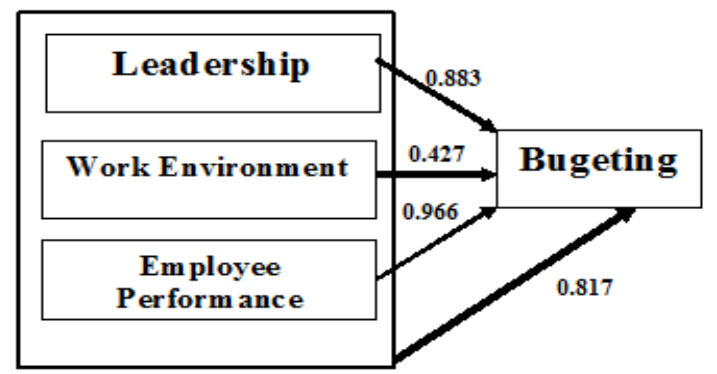

Figure 2 the calculation on structural equation a model (standardized model)

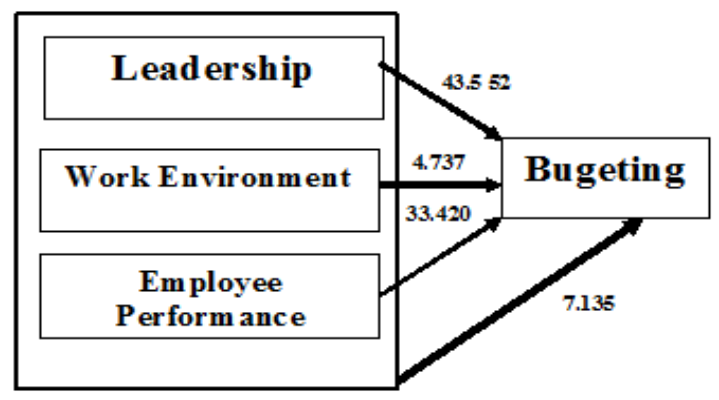

Figure 3 the calculation on structural equation a model (tvalue model)

Table 1 . The feasibility testing model structural equation model (SEM)

\begin{tabular}{|l|l|l|l|l|}
\hline No & $\begin{array}{l}\text { Goodness Of } \\
\text { Fit Index }\end{array}$ & $\begin{array}{l}\text { Research } \\
\text { result }\end{array}$ & $\begin{array}{l}\text { Cut off Value } \\
\text { (Nilai Batas) }\end{array}$ & $\begin{array}{l}\text { Conc } \\
\text { lusion }\end{array}$ \\
\hline 1 & $X^{2-}$ chi square & 20,121 & $\begin{array}{l}\leq \alpha . \mathrm{df} \\
\text { (smaller } \\
\text { than Chi } \\
\text { square } \\
\text { table) }\end{array}$ & Good \\
\hline 2 & $\begin{array}{l}\text { Significance } \\
\text { probability }\end{array}$ & 0,110 & $\geq 0,05$ & \\
\hline 3 & GFI & 0,971 & $\geq 0,90$ & Good \\
\hline 4 & AGFI & 0,959 & $\geq 0,90$ & Good \\
\hline 5 & CFI & 0,983 & $\geq 0,90$ & Good \\
\hline 6 & NNFI/TLI & 0,966 & $\geq 0,90$ & Good \\
\hline
\end{tabular}

\begin{tabular}{|l|l|l|l|l|}
\hline 7 & RMSEA & 0.027 & $\leq 0,08$ & Good \\
\hline 8 & CMIN/DF & 0.951 & $\leq 0,05$ & Good \\
\hline
\end{tabular}

The result of reckoning with the point of view of shem , fourth variable having goodness of a good fit, so that it can be passed on for testing a hypothesis that has been determined.

Table 2 .The results of the testing of hypotheses

\begin{tabular}{|l|l|l|l|l|l|}
\hline $\begin{array}{l}\text { Hypo } \\
\text { thesis }\end{array}$ & Deskription & Decision & C.R. & S.M.C & $\begin{array}{l}\text { Conclu } \\
\text { sion }\end{array}$ \\
\hline $\mathbf{H}_{\mathbf{1}}$ & $\begin{array}{l}\text { There is a } \\
\text { significant effect } \\
\text { of Leadership } \\
\text { of the budgeting }\end{array}$ & Suportive & 43.552 & - & $\begin{array}{l}\text { Direct } \\
\text { Effect }\end{array}$ \\
\hline $\mathbf{H}_{\mathbf{2}}$ & $\begin{array}{l}\text { There is } \\
\text { a significant } \\
\text { influence Work } \\
\text { Environment of } \\
\text { the budgeting }\end{array}$ & Suportive & 4.737 & - & $\begin{array}{l}\text { Direct } \\
\text { Effect }\end{array}$ \\
\hline $\mathbf{H}_{3}$ & $\begin{array}{l}\text { There is a } \\
\text { significant } \\
\text { effect of the } \\
\text { Employee } \\
\text { Performance } \\
\text { of the budgeting }\end{array}$ & $\begin{array}{l}\text { Suportive } \\
\text { There is a } \\
\text { significant effect } \\
\text { of Leadership } \\
\text { and Work } \\
\text { Environment } \\
\text { together to } \\
\text { the budgeting }\end{array}$ & 33.420 & - & $\begin{array}{l}\text { Direct } \\
\text { Effect }\end{array}$ \\
\hline $\mathbf{H}_{\mathbf{4}}$ & Suportive & 9.885 & 7.135 & $\begin{array}{l}\text { Direct } \\
\text { Effect }\end{array}$ \\
\hline
\end{tabular}

\subsection{The results of the analysis}

1. The influence of leadership on the quality of the budgeting process value estimate standardized regression $0.88388,3 \%$ or amounting to as much as , based on the value of critical ratio / cr leadership against the budgeting process from the influence of non-competitive purchase will be 43.552 \& gt; 2 , so that it can be significant, so in full the leadership of significant impact on the budgeting process , it means the better leadership then it would be more high the budgeting process manufacturing in the new company in the industrial park surya cipta karawang-west java

2. The influence of work environment against the budgeting process value estimate standardized regression $0.42742 .7 \%$ or amounting to as much as .The value of a critical ratio / cr to the influence of work environment against the budgeting process non-competitive purchase will be in full 4.737 \& gt; 2 , so that work environment significant impact on the budgeting process, it means the better work environment so the budgeting process will be getting better.

3. The influence of employee performance against budgeting value estimate standardized regression of 0.966

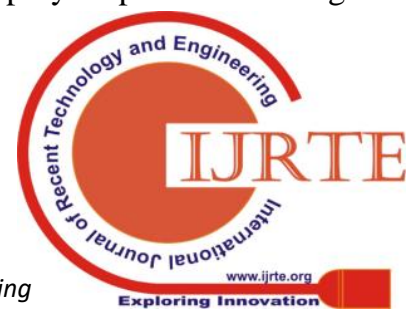


or amounting to $96.6 \%$, value critical ratio / cr from the influence of employee performance against budgeting is of $33.420 \& \mathrm{gt} ; 2$, so that it can be said significant, it means the function properly of employee performance so budgeting will be getting better.

4. The influence of leadership, work environment and variable of employee performance together to budgeting variable influence leadership, work environment and variable of employee performance together on variables budgeting is of: $0.817 \times 100 \%$ $=81.7 \%$, the rest of $43.1 \%$ influenced by other factors. On the value fhitung greater than the ftabel is as much as $7.135 \& \mathrm{gt} ; 1.318$, so that the phitung obtained of the value of ptabel 0.000 \& lt; 0.05.Thus to companies manufacturing in the industrial park Surya Cipta Karawang-West Java positively by leadership, environment

\section{Conclusion}

1. Leadership in full have had a positive impact and significantly to the budgeting process. It showed that the that leadership owned company is getting better the more one is improve the quality of the quality of the budgeting process

2. It has some positive effects in full work environment and significantly to the budgeting process. It shows that when a work environment conducive or good the more one is good company the budgeting process.

3. It has some positive effects of employee performance in full and significantly to the budgeting process. This indicates that with the performance of employees that have been getting better the more one is improve the quality of the budgeting process .

4. Leadership, work environment and of employee performance simultaneously it has some positive effects and significantly to the budgeting process. Of the three partial considered as variable, it turns out that the most significant impact on an influential leadership the budgeting process. This means that, that the lower the good leadership is getting better budgeting system.

\subsection{Suggestions}

1. Having the value of the kepemipinan the lowest average is in the ability of control emotional condition, to achieve objectives have is set by the company, by providing support to the activities of the achievement of a goal a good budgeting, so will increase the company performance.

2. Having the value of the employee performance the lowest average is not achieve the target of this work as specified portray a about the performance of a very strong impact. To improve its target of employee performance are required to have the ability to target based work performance thus of employee performance would reflect activities that both in improving the performance of employees.
3. A work environment of the lowest rata-rata is the lack of an organization convey a message that nilai-nilai ethics and integrity, led a sympathetic to problems or difficulties (empathy) to solving personal persoalanpersoalan faced by employees.This will mempermuda leaders in infuse nilai-nilai ethics and integrity organization in raising a work environment conducive and budgeting process will be better, this must not dikompromi.

4. Penganggran that have value rata-rata the lowest in research is the uncertainty strategy or the turbulence of external so as not to achieve pengnggran good.It can be achieved if done revision budgeting process to improve efesiensi and effectiveness of budgeting process itself.

\subsection{The limited number of research and further investigation.}

There are still many other aspects which can be used as variable this research. So as to allow the outcome of the findings in this research there are still limited. The limitations come in among other:

1. Limited first: this research using kuisioner as instrument to collect data. The situation and psychological state respondents very influential while giving a response to the proposed statement, then possible produce numbers less described the situation and the conditions are actually.

2. Limited both: this research new with four variable (leadership, workplace, employee performance and budgeting process) to know and measuring budgeting process, according to researchers are still factors / other variables allegedly also contribute or affecting budgeting process. But other variables that in intent include: professionalism and education and training

3. Limited third: the study is done in one sector at the rate on one industrial estate so the results are still be have been significant. Should be done is performed broader and more.

4. With respect to point three above, further investigation that can be researchers recommend is as follows:

a. of this study was conducted the regional level (the provincial government) all several manufacturing companies who exist or listed at the indonesian stock exchange

b. of this study was conducted by the use of the method of analysis that differed as analysis by using lisrel shem, pls, spss, and other path

Ethical clearance - Not required

Source of funding- Self

Conflict of Interest - Nil

References

[1] Arif, Bahtiar, Muchlis, Iskandar; Akuntansi 
Pemerintahan. Akademia Jakarta, 2009.

[2] Bataona, Marco, Strategi Jitu Memilih Pemimpin Melalui Program Managemen Trainee., Jakarta, Quantum Bisnis dan Manajemen, 1997.

[3] BPKP. Pedoman Penyusunan Anggaran Berbasis Kinerja (Revisi), 2010. <http://www.bpkpp.go.id

[4] David, N and Hayman 2009 Public Finance: A Contemporary Application of Theory to Policy Sevent Edition, Orlando USA; The Dryden Press Hesket and Kotter, 1997, What Leaders Really Do, Cetakan keempat, jilid dua, Jakarta, Bhuana Ilmu Populer.

[5] Dessler, Gary, Kepemimpinan Tim untuk membawa Perubahan, Edisi Kelima, Alih bahasa Sujanto F.X., Jakarta, PT. Raja Grafindo Persada, 2004.

[6] Dwi Handono dan Amin Subargus, Hubungan Kinerja Karyawan Tata Usaha dengan Kepuasan Kerja Dosen (Studi empirik pada Politeknik Kesehatan Palu) 2008.

[7] Govindarajan Robert N. Antony Vijay; Management Control System. Singapore Mc Graw-Hill Irwin, 2005.

[8] Hansen \& Mowen; Management Accounting. Singapore Thomson Asia Pte Ltd, 2009.

[9] H. Hasanudin, Pengaruh kepemimpinan terhadap produktivitas kerja (Studi empirik pada Perusahaan Garmen di Wilayah Bandung), 2004.

[10] H. Slamet Widodo, Pengaruh Perilaku Pemimpin, Karakteristik Pribadi, Lingkungan Kerja dan Pengharapan terhadap Kepuasan Kerja Karyawan (Studi empirik pada PT Pupuk Sriwijaya Palembang-Sumatera Selatan), 2008.

[11] Luthans, Fred, Perilaku Organisasi., Edisi dua, Terjemahan, McGrawHill Companies, Inc., Jakarta, Gramedia, 2006.

[12] Mahsum Mohamad dan Mardiasmo; Pengukuran Kinerja Sektor Publik. Yogyakarta BPFE, 2009.

[13] Mardiasmo, Otonomi dan Manajemen Keuangan Daerah, Ed. II, Yogyakarta: Andi Yogyakarta, 2009.

[14] Rama, Pengaruh Kepemimpinan dan Lingkungan Kerja terhadap Intensi Turnover (Studi empirik pada Bank Swasta Nasional Jakarta), 2010.

[15] Ridwan, dan Kuncoro, Engkos .A, Cara Menggunakan dan Memakai Analisis Jalur (Path Analysis)., Bandung : Alfabeta Robbins, Stephen. P, 2002, Prinsip-Prinsip Perilaku Organisasi, Alih Bahasa Halida dan Dewi Sartika, Edisi Kelima, Jakarta, PT Gelora Aksara Pratama, 2007.

[16] Robbins, Stephen. P, Perilaku Organisasi: Konsep, Kontroversi, Aplikasi, Alih Bahasa Hadyana Pujaatmaka, Jilid 2, Edisi Tujuh, Jakarta, PT Prenhallindo. Robbins, Stephen. P, 2006, Perilaku Organisasi, Alih Bahasa Drs. Benyamin Molan, Edisi Kesepuluh, Jakarta, PT Indeks, Kelompok Gramedia, 2006.

[17] .Siegel Joe G., Budgeting. Jakarta Erlangga Simamora, 2009, Pengaruh Lingkungan kerja Terhadap Intensi Turnover Pada PT. Perkasa Mostindo Utama Binjai Deli Serdang, Jurnal Akuntansi dan Manajemen, STIE YKPN, Yogyakarta, Vol. xvi, No.1, April, 2006.

[18] Supranto, J, Statistik Teori dan Aplikasi, Edisi Keenam, Jilid satu, Jakarta, Erlangga, 2000.

[19] Titer Wahyanto, Pascasarjana Manajemen. Universitas Budi Luhur Jakarta, 2011.

[20] Winardi, J, Manajemen Perilaku Organisasi, Jakarta, Kencana Prenada Media group, 2005.

[21] Yuki, Kepemimpinan dan Kinerja Karyawan dalam Penerapan Teori Fiedler.(Studi empirik pada kantor-kantor cabang Bank di Yogyakarta), 2008. 